\title{
Proposed Selection Criteria of Contractors in the Egyptian Construction Projects Biddings
}

\author{
Ahmed F. Atia \\ Master student, Structural Eng. \\ Dept., Faculty of Engineering, \\ Tanta University, Tanta, Egypt
}

\author{
Haytham M. Sanad \\ Lecturer at Structural Eng. Dept., \\ Faculty of Engineering, Tanta \\ University, Tanta, Egypt
}

\author{
Emad El-sayed Etman \\ Professor at Structural Eng. Dept., \\ Faculty of Engineering, Tanta \\ University, Tanta, Egypt
}

\begin{abstract}
The difficulty of selection of contractors in Egypt as a result of multiple and different criteria to select contractors and the different relative weights from one project to another has always been the main factors of the problem. There is a need to determine selection criteria of contractors for construction projects, as well as determine relative weights of the selection criteria. This issue has been of interest for many decades and remains a contemporary subject because of the rapid modernization of construction project management. This research utilizes an investigation approach to achieve the research goals and design and perform a questionnaire to collect real-life information covering relevant parties. Results showed that, a total of (15) main criteria, (67) sub-criteria were investigated as the most important criteria. The most important criteria are "experience, working schedule, bid specific, general information \& registration details and management \& organization of the contractor". It is very useful to practitioners intending to engage in construction projects in the Middle East due to the similar trends and current practices. The paper concerns with providing construction managers and professionals with recommendations in pursuit of better evaluation of constructors in Egypt and Middle East.
\end{abstract}

Keywords: selection criteria, Egyptian, Construction, Projects management, tenders, biddings, quotations, evaluation.

\section{INTRODUCTION}

The selection of contractors in Egyptian construction projects always cause problems for decision makers (owners), there are no permanent criteria of this selection. Criteria for this selection vary depending on construction projects and several conditions. Determining these criteria lead to positive results on both sides (the decision makers and the contractors). These criteria make it easier for decision-makers in Egypt to choose between contractor's applicants for construction projects. Also, it is helpful for contractors to know the important selection criteria for construction in Egypt to comply with. The Egyptian construction industry needs a robust database system capable of providing the decision maker with the accurate information necessary for contractors' selection process. This information should reflect upon technical experience, managerial experience, past owner/contractor relationship, past performance and quality, past failures and the contractor's history of claims and arbitration. The Egyptian construction industry should have a decision support software package that helps owners and professionals in evaluating the pre-qualification and biding data. The software should have a database for the different evaluation criteria and the recommended relative weights as function of project aforementioned variables. It should be simple, flexible, and user-friendly yet considers the different and specific characteristics of the construction industry in Egypt.

\section{LITERATURE REVIEW}

The literature indicates a wide range of evaluation criteria that are being used to evaluate contractors' overall suitability. A thorough review of the literature reveals the existence of various criteria, different information types, and different assessment methods. In order to conduct the research investigation, it is necessary to study the global practices for the bid-prequalification process that are frequently being used by the industry, researchers, and practitioners. There are a lot of criteria which must be determined before this selection; these depend on the clients of the project if it is public or private. This also depends on the type of the project. The followings are some of previous studies that aim at determining the most important criteria for implementing a contractor selection process.

Tarawneh (2004) used about thirty-one prequalification criteria including: work quality, executing projects, handling safety requirements, managerial capability, financial stability, previous track record, past experience, current workload and obligations, reputation ... etc.

Anagnostopoulos \&Vavatsikos (2006) determined criteria and sub-criteria in their hierarchy level that include financial performance (credit ratio, current ratio, asset turnover ratio, etc.), technical performance (resources and experience), safety and health policy (compensation paid to labor accidents, safety and health investment), and public work past performance (cost overruns, schedule overruns, and claims). Waara and Brochner (2006) benefitted from the criteria which were used at Swedish municipalities. These criteria and sub-criteria are presented in Table (1).

TABLE 1

SWEDISH MUNICIPALITIES CRITERIA (WAARA AND BROCHNER 2006)

\begin{tabular}{|c|c|}
\hline $\begin{array}{c}\text { Swedish public } \\
\text { procurement Act. }\end{array}$ & Criteria and sub-criteria \\
\hline Quality & quality assurance system - Quality plan \\
\hline Price and Cost & Bid price - Unit price \\
\hline $\begin{array}{c}\text { Performance } \\
\text { technical }\end{array}$ & Technical solution \\
\hline Technical features & Technical design \\
\hline $\begin{array}{c}\text { Environmental } \\
\text { impact }\end{array}$ & $\begin{array}{c}\text { Environmental characteristics - Environmental } \\
\text { management system - Corporate environmental } \\
\text { policy }\end{array}$ \\
\hline
\end{tabular}




\begin{tabular}{|c|c|}
\hline Running costs & $\begin{array}{l}\text { Operation costs - Maintenance Costs - Life-cycle } \\
\text { costs }\end{array}$ \\
\hline $\begin{array}{c}\text { Service Technical } \\
\text { support }\end{array}$ & Service - Responsiveness - availability \\
\hline Others & $\begin{array}{c}\text { Project duration - Contractor capabilities } \\
\text { Skills, training, references, past experience, and past } \\
\text { performance } \\
\text { Construction methods - Financial capacity } \\
\text { Solidity Health and safety Conformity with bidding } \\
\text { documents }\end{array}$ \\
\hline
\end{tabular}

Al-dughaither (2006) investigated several criteria such as; financial stability, capacity, operation and equipment, technical experience, performance record, managerial capabilities, and safety records. Banaitiene and Banatis (2006) showed that the most important criteria to be used are: financial strength, work capacity, experience, quality, and type of contract, as listed in Table 2.

Manideepak et al. (2009) proposed criteria such as bid amount, financial soundness, technical ability, management capability, safety and health records and reputation. Watt et al. (2010) determined the criteria involve: quality, track record, expertise, relevant experience, safety record, capability, and cost. Moreover, he determined the relative importance of each criterion compared with others Figure (1).

TABLE 2

CONTRACTOR EVALUATION CRITERIA (BANAITIENE AND BANATIS 2006)

\begin{tabular}{|c|c|}
\hline Bid Price & Insurance \\
\hline Legal Activity & Competitiveness \\
\hline Adequacy of contractor & Clients' appreciation \\
\hline Claims \& contractual disputes & Quality assurance \\
\hline Failed contracts & Experience \\
\hline Bankruptcy possibilities & Environmental protection \\
\hline Qualification of technical personnel & Safety and health at work \\
\hline \multicolumn{2}{|c|}{ Type and size of past projects } \\
\hline
\end{tabular}

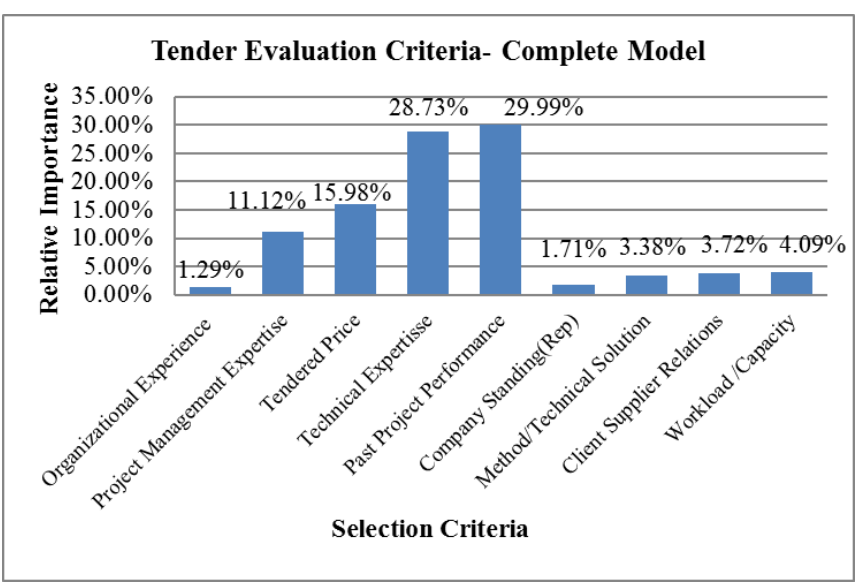

Figure 1. Relative importance of contractor evaluation criteria (Watt et al. 2010)

Trivedi et al. (2011) suggested six criteria, namely financial turnover, manpower resources, equipment resources, past experience, and past performance. Huang (2011) listed significant factors including: financial standing such as: financial stability, profit, turnover, technical ability, management capability, safety, current projects involving size, project location, and past owner cooperation with contractors. Puri et al. (2014) the following list includes most of the components that should be examined when conducting a contractor qualification. (1) Financial standing, such as financial stability, turnover, profit, obligations, amounts due, and owned financial funds. (2) Technical ability, such as experience, plant and equipment, and personnel. (3) Management capability, such as past performance and quality, quality control policy, quality management system, project management system, experience of technical personnel, and management knowledge. (4) Quality, safety, senior management, including experience, tenure with firm, and division of responsibilities. (5) Current projects/backlog, including number, size, and location of projects, percent of capacity being utilized, and status and expected completion, past failures in completed projects, number of years in construction, past client relationships and cooperation with contactors.

Molla et al. (2015) from 1985 to 2012, a total of 18 main criteria, containing a total of 163 sub-criteria, were used during the contractors' bid prequalification process. . The main criteria are 1) general information and registration detail, 2) experience, 3) project specific, 4) references, 5) management and organization, 6) resources, 7) finances, 8) methodology, 9) working schedule, 10) quality, 11) safety, 12) communication, 13) claim history, 14) capability, 15) subcontracting, 16) estimation, 17) strategic business, and 18) bid specific.

Chiang et al. (2017) the most important criterion in evaluating the contractor-prequalification process Technical ability and management capability. Financial soundness is the third most important criterion for contractor prequalification. The last two criteria weights for contractor prequalification are reputation and health and safety. This indicates that construction-project owners are either not very concerned about or unlikely to reference contractors' reputation and health and safety, as listed in Table (3).

TABLE 3

CONTRACTOR EVALUATION CRITERIA (BANAITIENE AND BANATIS 2006)

\begin{tabular}{|c|c|c|c|c|c|}
\hline Criterion & $\begin{array}{c}\text { Technical } \\
\text { ability }\end{array}$ & $\begin{array}{c}\text { Management } \\
\text { capability }\end{array}$ & $\begin{array}{c}\text { Financial } \\
\text { soundness }\end{array}$ & Reputation & $\begin{array}{c}\text { Health } \\
\text { and } \\
\text { safety }\end{array}$ \\
\hline weight & 0.243 & 0.239 & 0.219 & 0.168 & 0.131 \\
\hline
\end{tabular}

Salama et al. (2006) In Egypt, the process of contractor selection for the public projects is regulated by Act 89/1998. This act was introduced to replace Act 9. Despite introducing a point system to evaluate both the technical and financial offers, the Act still has some disadvantages. First, it did not mandate the use of the point system for contractors' evaluation. Second, it did not provide project managers and professionals with any criteria that could be taken into consideration for evaluating contractors' bids both technically and financially. Third, it only focuses on the bid price in evaluating financial offers.

\section{AIMS OF RESEARCH}

The primary objectives of this investigating study are to:

1. Giving decision makers (owners, consultants, sponsors, and governmental agencies) the main selection criteria for contractors, to facilitate and professionalize the selection process among contractors in construction projects. 
2. Giving contractors important criteria that they should focus on, and work on developing their capabilities to match with them, within their organizations.

3. Recovering and investigating wide-range of selection criteria including those ignored in previous similar studies in different world countries and particularly in Egypt.

\section{SELECTION CRITERIA}

According to the literature review and to develop a reliable and valid research steps, the initial survey resulted with criteria were assessed and revised to satisfy validity to ensure its readability, clarity, completeness, relevance, and applicability. Investigation was done based on the feedbacks obtained from some academics and experts. As a result of this questionnaire, Table (4) summarizes the fifteen main criteria and (67) sub-criteria that may be used in the contractor selection.

\section{DATA ANALYSIS}

This phase involves the analysis of the data received from the responses to the questionnaire survey. A total of 105 completed questionnaires were received back from the director's general projects in companies at construction engineer. Data was analyzed using SPSS and Microsoft Excel. Analysis of the data received was conducted through employing a straightforward descriptive statistical process such as percentages, graphics, tables and summary of the results.

\subsection{Reliability}

This section aims to investigate the Reliability of the questionnaire survey through Cronbach's Alpha by used SPSS program version 22. Table (5) displays the Reliability Statistics of the questionnaire; it shows that about Cronbach's Alpha is 0.960 that is veer good for Reliability Statistics of the questionnaire.

TABLE 4

CONTRACTOR SELECTION CRITERIA AND SUB-CRITERIA

\begin{tabular}{|c|c|c|}
\hline No. & Criterion (15) & Sub-Criterion (67) \\
\hline 1 & $\begin{array}{l}\text { General } \\
\text { Information and } \\
\text { Registration } \\
\text { Details }\end{array}$ & $\begin{array}{l}\text { [1]Qualification grade [2]Familiarity with } \\
\text { regulating authorities [3]Age of shareholders } \\
\text { [4]Organizational structure }\end{array}$ \\
\hline 2 & Experience & $\begin{array}{l}\text { [1]Length of time company controlled by } \\
\text { current management [2]General work } \\
\text { experience [3]Specialist work experience } \\
\text { [4]Recent completed projects [5]Past } \\
\text { performance in owner previous project } \\
\text { [6]Classes of work performed in each project } \\
\text { [7]Business coverage }\end{array}$ \\
\hline 3 & References & $\begin{array}{l}\text { [1]Largest similar project performed in past } 5 \\
\text { years [2]Company image-historical non- } \\
\text { performance [3]Good relationship with past } \\
\text { project owners }\end{array}$ \\
\hline 4 & $\begin{array}{l}\text { Management } \\
\text { and } \\
\text { Organization }\end{array}$ & $\begin{array}{l}\text { [1]Leader's personality and capability } \\
\text { [2]Professional Contract management } \\
\text { [3]Logistic and supply chain management } \\
\text { [4]Design and consultant management } \\
\text { [5]Purchasing experience, material handling } \\
\text { and control }\end{array}$ \\
\hline 5 & Resources & $\begin{array}{l}\text { [1]Techno-ware Technology } \\
\text { availability[2]Equipment operational } \\
\text { experience [3]Availability of product and price } \\
\text { information of labor, materials, plants, and all } \\
\text { resources [4]Availability of testing equipment }\end{array}$ \\
\hline
\end{tabular}

\begin{tabular}{|c|c|c|}
\hline & & $\begin{array}{l}\text { as quality assurance [5]Ownership of equipment } \\
\text { versus ability to rent it [6]quantities and } \\
\text { condition of the owned equipment }\end{array}$ \\
\hline 6 & Quality & $\begin{array}{l}\text { [1]Quality management system[2]Achievement } \\
\text { of quality level[3]Awarding ISO certification }\end{array}$ \\
\hline 7 & Methodology & $\begin{array}{l}\text { [1]Environmental } \\
\text { considerations[2]Specialization of particular } \\
\text { construction method[3]Statement of } \\
\text { methodology }\end{array}$ \\
\hline 8 & Finance & $\begin{array}{l}\text { [1]Quality of financial statement[2]Experience } \\
\text { of accountants[3]Current commitments } \\
\text { [4]Capital[5]Current and fixed assets[6]Projects } \\
\text { completed on budget }\end{array}$ \\
\hline 9 & Safety & $\begin{array}{l}\text { [1]Health and safety performance and plan } \\
\text { [2]Security [3]Health and safety records } \\
\text { [4]Availability of liability and workers } \\
\text { compensation insurance policies }\end{array}$ \\
\hline 10 & Communication & $\begin{array}{l}\text { [1]Communication [2] Documentation } \\
\text { management [3] Customer service, } \\
\text { Inadequately reception arrangements for } \\
\text { telephone message at head-office. }\end{array}$ \\
\hline 11 & $\begin{array}{l}\text { Working } \\
\text { Schedule }\end{array}$ & $\begin{array}{l}\text { [1]Projects completed on time[2]Scheduling of } \\
\text { resources[3]Scheduling of cost } \\
\text { control[4]Applying monthly or periodic update } \\
\text { to schedules }\end{array}$ \\
\hline 12 & $\begin{array}{l}\text { Claiming } \\
\text { History }\end{array}$ & $\begin{array}{l}\text { [1]Current claims in court or arbitration } \\
\text { [2]Engaged in fraudulent activity [3]Claim and } \\
\text { dispute resolving skills [4]Knowledge and } \\
\text { expertise on law [5]Contract not renewed due to } \\
\text { failure to perform }\end{array}$ \\
\hline 13 & Subcontracting & $\begin{array}{l}\text { [1]Percentage of subcontracted work } \\
\text { [2]Subcontractor prequalification process } \\
\text { [3]Management of subcontractors [4]Standard } \\
\text { of subcontractors' works in past projects }\end{array}$ \\
\hline 14 & $\begin{array}{l}\text { Strategic } \\
\text { Business }\end{array}$ & $\begin{array}{l}\text { [1]Time and cost saving considerations (e.g. } \\
\text { application of value engineering) [2]Strategic } \\
\text { awareness and perspective [3]Strategy } \\
\text { implementation [4]Motivation and job } \\
\text { satisfaction [5]Technological innovation ability } \\
\text { [6]Market research and planning [7]Existence } \\
\text { of research and development dept. }\end{array}$ \\
\hline 15 & Bid Specific & $\begin{array}{l}\text { [1]Bidding strategy [2]Experience in bidding } \\
\text { [3]Bidding resources }\end{array}$ \\
\hline
\end{tabular}

TABLE 5

RELIABILITY STATISTICS OF THE QUESTIONNAIRE

\begin{tabular}{|c|c|}
\hline \multicolumn{2}{|c|}{ Reliability Statistics } \\
\hline Cronbach's Alpha & N of Items \\
\hline .960 & 67 \\
\hline
\end{tabular}

\subsection{Respondents' Characteristics}

This section aims to investigate the characteristics of the respondents who respond to the questionnaire survey through answering several questions such as; the contact information of respondents like: the name, the telephone number and the Email address. It was remarkable from the received questionnaire that most of the respondents fill this optional data. Other information required includes: the respondent's level of education, the respondent's job title, the respondent's role during the selection or the prequalification of the construction contractor.

\subsubsection{Respondents level of education}

The results as illustrated in Figure (2) indicate that about $(74.3 \%)$ of the respondents have a bachelor degree, followed by the respondents have a master degree with $(17.1 \%)$ percent, and the respondents having a Ph.D. are with $(8.6 \%)$ percent. 


\subsubsection{Respondent job title}

As displayed in Figure (3), it is found that the majority of the respondents about (56.2\%)were site engineers, (24.8\%) were construction managers, $(17.1 \%)$ were Engineering Consultant whereas remaining $(1.9 \%)$ of respondents were academic professor.

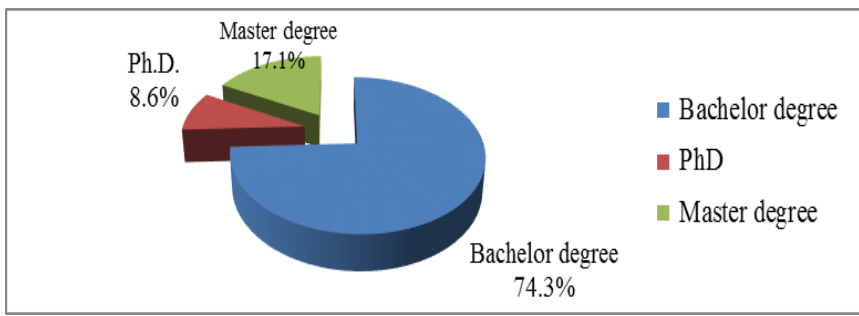

Figure 2. Respondents' level of education

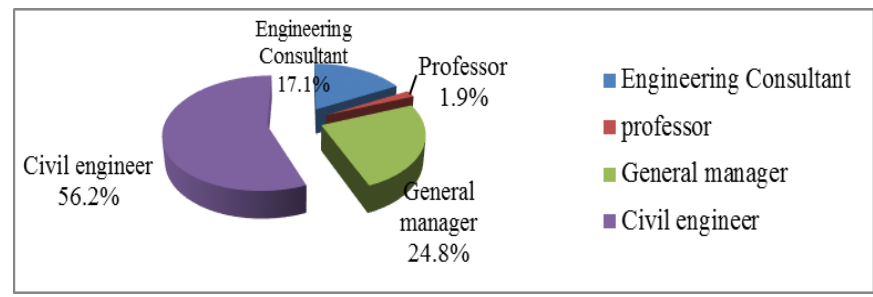

Figure 3. Job title of respondents

\subsubsection{Respondents Specialization}

It is found that the majority of the respondents about (65.7\%) were Design/Consulting, whereas remaining (34.3\%) are Execution/Contracting.

\subsubsection{Experience of respondents}

About $(30.5 \%)$ of the respondents have less than 5 years of experience, $(23.8 \%)$ between (5-10) years, $(8.6 \%)$ between $(10-15)$ years, and about $(37.1 \%)$ have work experience more than 15 years.

\subsubsection{Type of organization}

About (37.1\%) of the respondents are working for Sector/Private, (23.8\%) for Enterprise/Public, and about $(39 \%)$ have working for Government.

\subsection{Statistical Results for Criteria}

Table (6) shows the Relative importance Index for Main Criteria. Determined the range of criteria from (3.3918) to (2.8571) and the range of Std. Deviation ratio from (0.36852) to $(0.72055)$, the maximum mean for main criteria is Experience and the minimum mean for main criteria is Safety.

TABLE 6

RELATIVE IMPORTANCE INDEX FOR MAIN-CRITERIA

\begin{tabular}{|l|c|c|}
\hline Main Criteria & Mean & Std. Deviation \\
\hline General Information and Registration & 3.2754 & .45777 \\
\hline Experience & 3.3918 & .36852 \\
\hline References & 3.1714 & .49163 \\
\hline Management and Organization & 3.2171 & .54640 \\
\hline Resources & 2.9937 & .58284 \\
\hline Quality & 3.1048 & .57422 \\
\hline
\end{tabular}

\begin{tabular}{|l|l|l|}
\hline Methodology & 2.9905 & .58371 \\
\hline Finance & 3.1356 & .53939 \\
\hline Safety & 2.8571 & .63251 \\
\hline Communication & 2.9270 & .72055 \\
\hline Working Schedule & 3.3833 & .48296 \\
\hline Claiming History & 3.2095 & .64174 \\
\hline Subcontracting & 3.1762 & .59739 \\
\hline Strategic Business & 3.0249 & .63243 \\
\hline Bid specific & 3.3079 & .71267 \\
\hline
\end{tabular}

Table (7) shows top five main-criteria based on the highest mean.

TABLE 7

TOP FIVE MAIN CRITERIA

\begin{tabular}{|c|l|c|}
\hline No. & \multicolumn{1}{|c|}{ Main-criteria } & Mean \\
\hline $\mathbf{1}$ & Experience & 3.3918 \\
\hline $\mathbf{2}$ & Working Schedule & 3.3833 \\
\hline $\mathbf{3}$ & Bid Specific & 3.3079 \\
\hline $\mathbf{4}$ & General Information and Registration Details & 3.2754 \\
\hline $\mathbf{5}$ & Management and Organization & 3.2171 \\
\hline
\end{tabular}

Table (8) shows a sort of the main criteria and sub criteria by the mean.

TABLE 8

SORTING THE MAIN CRITERIA AND SUB CRITERIA

\begin{tabular}{|c|c|c|c|c|}
\hline No. & Main criteria & Mean & Sub-Criteria & Mean \\
\hline \multirow[t]{7}{*}{1} & \multirow[t]{7}{*}{ Experience } & \multirow[t]{7}{*}{3.3918} & Specialist work & 3.6857 \\
\hline & & & Past performance in & 3.6442 \\
\hline & & & Business coverage & 3.5905 \\
\hline & & & General work experience & 3.5714 \\
\hline & & & Recent completed & 3.4571 \\
\hline & & & Classes of work & 3.1048 \\
\hline & & & Length of time company & 2.6923 \\
\hline \multirow[t]{4}{*}{2} & \multirow[t]{4}{*}{ Working Schedule } & \multirow[t]{4}{*}{3.3833} & Projects completed on & 3.5048 \\
\hline & & & Scheduling of cost & 3.3714 \\
\hline & & & Scheduling of resources & 3.3333 \\
\hline & & & Applying monthly or & 3.3238 \\
\hline \multirow[t]{3}{*}{3} & \multirow[t]{3}{*}{ Bid Specific } & \multirow[t]{3}{*}{3.3079} & Experience in bidding & 3.3786 \\
\hline & & & Bidding strategy & 3.3143 \\
\hline & & & Bidding resources & 3.2381 \\
\hline \multirow[t]{4}{*}{4} & \multirow{4}{*}{$\begin{array}{l}\text { General } \\
\text { Information and } \\
\text { Registration } \\
\text { Details }\end{array}$} & \multirow[t]{4}{*}{3.2754} & organizational structure & 3.5524 \\
\hline & & & Qualification grade & 3.4762 \\
\hline & & & Familiarity with & 3.1442 \\
\hline & & & Age of shareholders & 2.9238 \\
\hline \multirow[t]{5}{*}{5} & \multirow{5}{*}{$\begin{array}{l}\text { Management and } \\
\text { Organization }\end{array}$} & \multirow[t]{5}{*}{3.2171} & Professional Contract & 3.3238 \\
\hline & & & Logistic and supply chain & 3.3048 \\
\hline & & & Design and consultant & 3.1905 \\
\hline & & & Leader's personality and & 3.181 \\
\hline & & & Purchasing experience, & 3.0865 \\
\hline \multirow[t]{5}{*}{6} & \multirow[t]{5}{*}{ Claiming History } & \multirow[t]{5}{*}{3.2095} & Engaged in fraudulent & 3.4476 \\
\hline & & & Contract not renewed due & 3.3143 \\
\hline & & & Claim and dispute & 3.1143 \\
\hline & & & Knowledge and expertise & 3.1048 \\
\hline & & & Current claims in court or & 3.0667 \\
\hline \multirow[t]{4}{*}{7} & \multirow[t]{4}{*}{ Subcontracting } & \multirow[t]{4}{*}{3.1762} & Management of & 3.3143 \\
\hline & & & Standard of & 3.2952 \\
\hline & & & Subcontractor & 3.1333 \\
\hline & & & Percentage of & 2.9619 \\
\hline \multirow[t]{3}{*}{8} & \multirow[t]{3}{*}{ References } & \multirow[t]{3}{*}{3.1714} & Largest similar project & 3.4519 \\
\hline & & & Good relationship with & 3.0762 \\
\hline & & & Company image- & 2.9905 \\
\hline \multirow[t]{6}{*}{9} & \multirow[t]{6}{*}{ Finance } & 3.1356 & Quality of financial & 3.4667 \\
\hline & & & Capital & 3.2571 \\
\hline & & & Projects completed on & 3.1442 \\
\hline & & & Experience of & 3.0857 \\
\hline & & & Current commitments & 3.000 \\
\hline & & & Current and fixed assets & 2.8571 \\
\hline
\end{tabular}




\begin{tabular}{|c|c|c|c|c|}
\hline \multirow[t]{3}{*}{10} & \multirow[t]{3}{*}{ Quality } & \multirow[t]{3}{*}{3.1048} & Achievement of quality & 3.4095 \\
\hline & & & Quality management & 3.1619 \\
\hline & & & Awarding ISO & 2.7429 \\
\hline \multirow[t]{7}{*}{11} & \multirow[t]{7}{*}{ Strategic Business } & \multirow[t]{7}{*}{3.0249} & Time and cost saving & 3.4286 \\
\hline & & & Technological innovation & 3.1238 \\
\hline & & & Market research and & 3.0667 \\
\hline & & & Strategic awareness and & 2.9619 \\
\hline & & & Strategy implementation & 2.9619 \\
\hline & & & Motivation and job & 2.9429 \\
\hline & & & Existence of research and & 2.6827 \\
\hline \multirow[t]{6}{*}{12} & \multirow[t]{6}{*}{ Resources } & \multirow[t]{6}{*}{2.9937} & Techno-ware Technology & 3.2095 \\
\hline & & & Equipment operational & 3.1619 \\
\hline & & & Availability of product & 3.1333 \\
\hline & & & Availability of testing & 3.0476 \\
\hline & & & quantities and condition & 2.9238 \\
\hline & & & Ownership of equipment & 2.4857 \\
\hline \multirow[t]{3}{*}{13} & \multirow[t]{3}{*}{ Methodology } & \multirow[t]{3}{*}{2.9905} & Statement of & 3.2095 \\
\hline & & & Specialization of & 3.1143 \\
\hline & & & Environmental & 2.6476 \\
\hline \multirow[t]{3}{*}{14} & \multirow[t]{3}{*}{ Communication } & \multirow[t]{3}{*}{2.927} & Communication & 3.2857 \\
\hline & & & Documentation & 2.8447 \\
\hline & & & Customer service, & 2.625 \\
\hline \multirow[t]{4}{*}{15} & \multirow[t]{4}{*}{ Safety } & \multirow[t]{4}{*}{2.8571} & Health and safety & 2.9714 \\
\hline & & & Security & 2.9524 \\
\hline & & & Availability of liability & 2.8095 \\
\hline & & & Health and safety records & 2.6952 \\
\hline
\end{tabular}

Table (9) shows top twenty sub-criteria based on the highest mean.

TABLE 9

TOP TWENTY SUB-CRITERIA

\begin{tabular}{|c|c|c|c|}
\hline No & Sub-criteria & Mean & Main criteria \\
\hline 1 & Specialist work experience & 3.6857 & Experience \\
\hline 2 & Past performance in owner's & 3.6442 & Experience \\
\hline 3 & Business coverage & 3.5905 & Experience \\
\hline 4 & General work experience & 3.5714 & Experience \\
\hline 5 & organizational structure & 3.5524 & $\begin{array}{l}\text { General Information and } \\
\text { Registration Details }\end{array}$ \\
\hline 6 & Projects completed on time & 3.5048 & Working Schedule \\
\hline 7 & Qualification grade & 3.4762 & $\begin{array}{l}\text { General Information and } \\
\text { Registration Details }\end{array}$ \\
\hline 8 & Quality of financial & 3.4667 & Finance \\
\hline 9 & Recent completed projects & 3.4571 & Experience \\
\hline 10 & Largest similar project & 3.4519 & References \\
\hline 11 & Engaged in fraudulent & 3.4476 & Claiming History \\
\hline 12 & Time and cost saving & 3.4286 & Strategic Business \\
\hline 13 & Achievement of quality level & 3.4095 & Quality \\
\hline 14 & Experience in bidding & 3.3786 & Bid Specific \\
\hline 15 & Scheduling of cost control & 3.3714 & Working Schedule \\
\hline 16 & Scheduling of resources & 3.3333 & Working Schedule \\
\hline 17 & $\begin{array}{l}\text { Applying monthly or } \\
\text { periodic update to schedules }\end{array}$ & 3.3238 & Working Schedule \\
\hline 18 & $\begin{array}{l}\text { Professional Contract } \\
\text { management }\end{array}$ & 3.3238 & $\begin{array}{l}\text { Management and } \\
\text { Organization }\end{array}$ \\
\hline 19 & Bidding strategy & 3.3143 & Bid Specific \\
\hline 20 & $\begin{array}{l}\text { Contract not renewed due to } \\
\text { failure to perform }\end{array}$ & 3.3143 & Claiming History \\
\hline
\end{tabular}

Table (10) shows the relative importance index for main criteria by specialization execution and contracting, design and consulting.
It is found that the top five for main criteria it is "Experience, working schedule, Bid Specific, General Information \& Registration Details and Management \&Organization". The descriptive for Std. Deviation by specialization execution and contracting, design and consulting for the top five criteria it is between (0.35459) and $(0.58655)$ is very close together. This indicates the convergence of views in this specialization, but the Std. Deviation by specialization design and consulting for Bid Specific is (0.78774) is different and this indicates different opinions in this specialization.

Table (11) shows the relative importance Index for main criteria by total years of experience $(0-5,5-10,10-15,>15)$. It is found that the Top five for main criteria it is "Experience, Working Schedule, Bid Specific, General Information \&Registration Details and Management \& Organization. The descriptive for Std. Deviation by total years of experience ( 0 $5,5-10,10-15,15<)$, for the top five criteria it is between $(0.33521)$ and $(0.58958)$ is very close together. This indicates the convergence of views for all years of experience, but the Std. Deviation by years of experience (5-10) for Bid Specific is (1.0000) is very big different and This shows that the opinions are very large dispersion in this part of year experience. As well the Std. Deviation by years of experience $(0-5)$ for Bid Specific is (0.68653) is different and this indicates different opinions in this part of year experience.

The Std. Deviation for main criteria "Experience, Working Schedule, General Information \& Registration Details and Management \&Organization" is very close together in specialization and total years of experience. This points to/shows the coming together of views as we show from Tables (10 and 11).

TABLE 10

RELATIVE IMPORTANCE INDEX FOR MAIN CRITERIA BY SPECIALIZATION

\begin{tabular}{|l|c|c|c|c|c|}
\hline \multirow{2}{*}{ Main Criteria } & \multirow{2}{*}{ Mean } & \multicolumn{4}{|c|}{ Mean for Specialization } \\
\cline { 3 - 6 } & & Execution and contracting & \multicolumn{2}{|c|}{ Design and Consulting } \\
\cline { 3 - 6 } & & Mean & Std. Deviation & Mean & Std. Deviation \\
\hline $\begin{array}{l}\text { General } \\
\text { Information and } \\
\begin{array}{l}\text { Registration } \\
\text { Details }\end{array}\end{array}$ & 3.2754 & 3.3542 & .42835 & 3.2343 & .47016 \\
\hline Experience & 3.3918 & 3.4722 & .35459 & 3.3499 & .37118 \\
\hline References & 3.1714 & 3.1667 & .54917 & 3.1739 & .46304 \\
\hline $\begin{array}{l}\text { Management } \\
\text { and } \\
\text { Organization }\end{array}$ & 3.2171 & 3.2667 & .46353 & 3.1913 & .58655 \\
\hline Resources & 2.9937 & 3.1111 & .54482 & 2.9324 & .59637 \\
\hline Quality & 3.1048 & 3.1574 & .61456 & 3.0773 & .55467 \\
\hline Methodology & 2.9905 & 3.0370 & .62629 & 2.9662 & .56344 \\
\hline Finance & 3.1356 & 3.2593 & .56265 & 3.0710 & .51933 \\
\hline Safety & 2.8571 & 2.8542 & .58668 & 2.8587 & .65932 \\
\hline Communication & 2.9270 & 3.0093 & .64972 & 2.8841 & .75586 \\
\hline $\begin{array}{l}\text { Working } \\
\text { Schedule }\end{array}$ & 3.3833 & 3.5000 & .44320 & 3.3225 & .49464 \\
\hline $\begin{array}{l}\text { Claiming } \\
\text { History }\end{array}$ & 3.2095 & 3.2167 & .65792 & 3.2058 & .63798 \\
\hline Subcontracting & 3.1762 & 3.4583 & .42046 & 3.0290 & .62505 \\
\hline $\begin{array}{l}\text { Strategic } \\
\text { Business }\end{array}$ & 3.0249 & 3.1667 & .58802 & 2.9510 & .64619 \\
\hline Bid Specific & 3.3079 & 3.4352 & .52746 & 3.2415 & .78774 \\
\hline
\end{tabular}


TOP FIVE MAIN CRITERIA

\begin{tabular}{|c|c|c|c|c|c|c|c|c|c|}
\hline \multirow{3}{*}{$\begin{array}{l}\text { Main } \\
\text { Criteria }\end{array}$} & \multirow{3}{*}{ Mean } & \multicolumn{8}{|c|}{ Mean for Total years of experience } \\
\hline & & \multicolumn{2}{|c|}{$15<$} & \multicolumn{2}{|c|}{ 10-15 } & \multicolumn{2}{|c|}{$5-10$} & \multicolumn{2}{|c|}{$0-5$} \\
\hline & & Mean & $\begin{array}{l}\text { Std. } \\
\text { Dev }\end{array}$ & Mean & $\begin{array}{l}\text { Std. } \\
\text { Dev }\end{array}$ & Mean & $\begin{array}{l}\text { Std. } \\
\text { Dev }\end{array}$ & Mean & $\begin{array}{l}\text { Std. } \\
\text { Dev }\end{array}$ \\
\hline $\begin{array}{l}\text { General } \\
\text { Informati } \\
\text { on\& } \\
\text { Registrat } \\
\text { ion } \\
\text { Details } \\
\end{array}$ & 3.2754 & 3.2500 & .41359 & 3.3333 & .43301 & 3.2367 & .43213 & 3.3203 & .54342 \\
\hline $\begin{array}{l}\text { Experien } \\
\text { ce }\end{array}$ & 3.3918 & 3.3736 & .33521 & 3.4921 & .35074 & 3.4057 & .34670 & 3.3750 & .43505 \\
\hline $\begin{array}{l}\text { Referenc } \\
\text { es }\end{array}$ & 3.1714 & 3.1880 & .51750 & 3.2593 & .54716 & 3.1333 & .53576 & 3.1563 & .42320 \\
\hline \begin{tabular}{|l|} 
Manage \\
ment and \\
Organiza \\
tion
\end{tabular} & 3.2171 & 3.1795 & .54056 & 3.3333 & .46904 & 3.1520 & .58958 & 3.2812 & .55150 \\
\hline $\begin{array}{l}\text { Resource } \\
\mathrm{s}\end{array}$ & 2.9937 & 2.9231 & .52960 & 3.0000 & .49301 & 3.0133 & .59884 & 3.0625 & .66633 \\
\hline Quality & 3.1048 & 3.1624 & .53460 & 3.1481 & .44444 & 3.0533 & .55008 & 3.0625 & .67965 \\
\hline \begin{tabular}{|l} 
Methodo \\
$\operatorname{logy}$
\end{tabular} & 2.9905 & 3.0256 & .57423 & 3.1111 & .50000 & 3.0000 & .48113 & 2.9063 & .69424 \\
\hline Finance & 3.1356 & 3.0812 & .46338 & 3.0741 & .74587 & 3.1893 & .49942 & 3.1771 & .60603 \\
\hline Safety & 2.8571 & 2.8654 & .68067 & 2.8056 & .80795 & 2.8200 & .53288 & 2.8906 & .61872 \\
\hline \begin{tabular}{|l|} 
Commun \\
ication
\end{tabular} & 2.9270 & 2.8974 & .71800 & 3.2222 & .40825 & 3.0000 & .79349 & 2.8229 & .73316 \\
\hline $\begin{array}{l}\text { Working } \\
\text { Schedule }\end{array}$ & 3.3833 & 3.3397 & .38682 & 3.6389 & .43501 & 3.4600 & .47148 & 3.3047 & .58797 \\
\hline \begin{tabular}{|l|} 
Claiming \\
History
\end{tabular} & 3.2095 & 3.1897 & .61721 & 3.4000 & 48990 & 3.3440 & .54320 & 3.0750 & .76158 \\
\hline $\begin{array}{l}\text { Subcontr } \\
\text { acting }\end{array}$ & 3.1762 & 3.1026 & .46140 & 3.3611 & .94465 & 3.2900 & .72053 & 3.1250 & .52363 \\
\hline \begin{tabular}{|l|} 
Strategic \\
Business \\
\end{tabular} & 3.0249 & 2.8987 & .62089 & 3.1429 & .51508 & 3.2457 & .59408 & 2.9732 & 67927 \\
\hline $\begin{array}{l}\text { Bid } \\
\text { Specific }\end{array}$ & 3.3079 & 3.3675 & .56088 & 3.4444 & .40825 & 3.1867 & 1.0000 & 3.2917 & .68653 \\
\hline
\end{tabular}

As displayed in Figure (4), determined the ratio of each criteria that an Owner can choose contractors and determine their performance that involved: "General Information \& Registration Details, Experience, References, Management \& Organization, Resources, Quality, Methodology, Finance, Safety, Communication, Working Schedule, Claiming History, Subcontracting, Strategic Business and Bid Specific". Moreover, he determined the relative importance of each criterion compared with others.

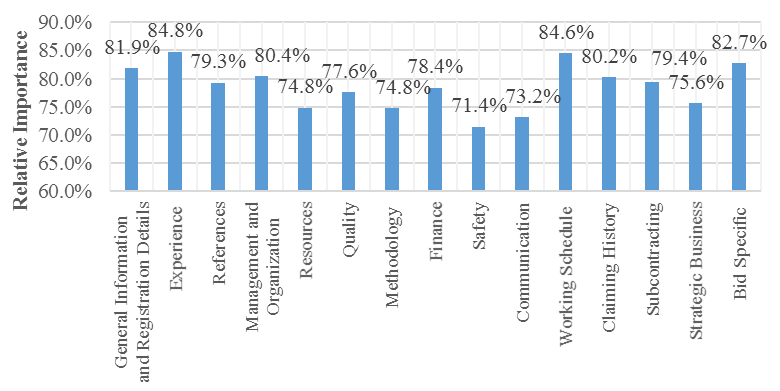

Main Criteria

Figure 4. Histogram of Relative importance Index for Main-Criteria

\section{SUMMARY AND CONCLUSION}

The selection of contractors in construction projects always cause problems for decision makers. These problems result from changed criteria and their weights from one project to another. Therefore, there is always a need to determine and update the selection criteria of contractors in construction projects, as well as determine the weights of these criteria. The determination of these criteria and their relative weights gives the decision makers flexibility for selection of contractors. The importance of research is that it gives decision makers in Egypt important criteria in the selection of contractors.

The most important criteria are "experience, working schedule, bid specific, general information \& registration details and management \& organization of the contractor", as we show in the figure (4). However, safety and communication at general acquired the lowest score from both consultants and contractors. Also, we can get the top five for main criteria and the top twenty for sub-criteria as we show in the tables (7 and 9). The result showed that, a total of (15) main criteria, (67) sub-criteria that is very important to select the contractors in Egypt. The limitations of the proposed selection criteria in popular project. Also, the study despite conducted in Egypt is useful to practitioners intending to engage in construction projects in the developing region of the Middle East due to the similar trends in current practices.

\section{REFERENCES}

[1] Tarawneh, S. (2004). 'Evaluation of Pre-qualification Criteria: Client Perspective; Jordan Case Study', Journal of Applied Sciences, vol. 4, no. 3.

[2] Anagnostopoulos, K \& Vavatsikos, A. (2006). "An AHP Model for Construction Contractor Prequalification", Operational Research. An International Journal, vol. 6, no. 3 .

[3] Waara, F., and Brochner, J. (2006). "Price and Non-price Criteria for Contractor Selection", Journal of Construction Engineering and Management, vol. 132, no. 8

[4] Al-dughaither, K. (2006). "A Multi-Criteria Decision-Making Model for Contractors Prequalification", Joint International Conference on Computing and Decision Making in Civil and Building Engineering, Montreal, Canada.

[5] Banaitiene, N., and Banaitis, A. (2006). "Analysis of Criteria for Contractors' Qualification Evaluation", Technological and Economic Development of Economy, vol.12, no. 4.

[6] Manideepak, G., Bhatla, A., and Pradhan, B. (2009). "Methodologies for Contractor Selection in Construction Industry', ACSGE, BITS Pilani, India.

[7] Watt, D., Kayis, B., and Willey, K. (2010). "The Relative Importance of Tender Evaluation and Contractor Selection Criteria", International Journal of Project Management, vol. 28, no.1.

[8] Trivedi, M., Pandey, M., and Bhadoria, S (2011). "Prequalification of Construction Contractor Using a FAHP", International Journal of Computer Applications, vol. 28, no. 10.

[9] Dwarika Puri, S.Tiwari. (2014). "Evaluating the Criteria for Contractors' Selection and Bid Evaluation", International Journal of Engineering Science Invention, vol.3, No. 7, pp.44-48.

[10] Molla, M., and Eric, A. (2015). "Factors Influencing Contractor Prequalification Processes in Developing Countries", International Journal of Architecture, Engineering and Construction Vol.4, December 2015, pp. 232-245.

[11] Fu-Yuan Chiang, Vincent F. Yu, and Pin Luarn. (2017). "Construction Contractor Selection in Taiwan Using AHP", International Journal of Engineering and Technology, vol.9, No. 3, pp.211-215.

[12] Salama, M., Abd El Aziz, H., El Sawah, H., and Samadony, A. (2006). "Investigating the criteria for contractors' selection and bid evaluation in Egypt", Proc. 22nd Annual ARCOM Conference, Birmingham, UK, pp. 531-540. 